Article

\title{
Efficacy of Oxyclozanide and Closantel against Rumen Flukes (Paramphistomidae) in Naturally Infected Sheep
}

\author{
David García-Dios $\left(\mathbb{D}\right.$, Pablo Díaz *(D), Miguel Viña, Susana Remesar ${ }^{\circledR}$, Alberto Prieto ${ }^{\mathbb{D}}$, \\ Gonzalo López-Lorenzo ${ }^{\mathbb{D}}$, Jose Manuel Díaz Cao, Rosario Panadero, Pablo Díez-Baños \\ and Ceferino Manuel López ${ }^{\mathbb{D}}$ \\ Investigación en Sanidad Animal: Galicia (Grupo INVESAGA), Department of Animal Pathology, \\ Faculty of Veterinary Medicine (Universidade de Santiago de Compostela), 27002 Lugo, Spain; \\ dgarciadios@gmail.com (D.G.-D.); mivivaz@gmail.com (M.V.); susana.remesar@usc.es (S.R.); \\ alberto.prieto@usc.es (A.P.); gonzalolopezlorenzo@gmail.com (G.L.-L.); jmdchh@gmail.com (J.M.D.C.); \\ rosario.panadero@usc.es (R.P.); pablo.diez@usc.es (P.D.-B.); c.lopez@usc.es (C.M.L.) \\ * Correspondence: pablo.diaz@usc.es; Tel.: +34-982-822129
}

Received: 15 September 2020; Accepted: 20 October 2020; Published: 22 October 2020

Simple Summary: Paramphistomosis, caused by ruminal trematodes, is currently considered an emergent disease in Europe due to the progressive increase of prevalence and reports of acute cases in ruminants. Thus, finding effective control methods such as efficient drugs against paramphistomids is currently a priority. Although some drugs have been found effective for treating paramphistomid infections in cattle, data in sheep are currently limited. A single administration of oxyclozanide $(15 \mathrm{mg} / \mathrm{kg})$ or closantel $(10 \mathrm{mg} / \mathrm{kg})$ has been proven efficient in cattle, but it has not been tested in sheep; thus, the aim of the present study was to assess the effectiveness of these treatment protocols against paramphistomids in naturally infected sheep. The treatment with oxyclozanide was very efficient since it significantly reduced the paramphistomid egg output in more than $90 \%$ during 11 weeks after treatment. In contrast, closantel showed low efficacies throughout the study. The results of this study support the use of a single oral dose of oxyclozanide at $15 \mathrm{mg} / \mathrm{kg}$ for treating paramphistomid infections in sheep, whereas a single oral dose of closantel at $10 \mathrm{mg} / \mathrm{kg}$ is not effective.

\begin{abstract}
Paramphistomosis is considered an emergent disease of ruminants in Europe. Some drugs have been found effective for treating paramphistomid infections in cattle, but data in sheep are currently limited. Thus, faecal samples from 25 adult sheep naturally infected with paramphistomids were collected weekly to test the efficacy of oxyclozanide and closantel. Three groups were performed: nine animals orally treated with a single dose of oxyclozanide $(15 \mathrm{mg} / \mathrm{kg}$ bodyweight $(\mathrm{BW})$ integrated the G-OXI group, whereas eight sheep orally treated with a single dose of closantel $(10 \mathrm{mg} / \mathrm{kg}$ BW) were placed in a group called G-CLS. Eight untreated controls constituted the group G-CON. Oxyclozanide showed efficacies up to $90 \%$ until week 11 post-treatment, with a maximum efficacy of $98.3 \%$, and significant differences were found between G-OXI and G-CON until the 26th week post-treatment. Closantel was insufficiently active (0-81\%) throughout the study and differences compared to G-CON were never found. The present study reveals that oxyclozanide given at a single oral dose of $15 \mathrm{mg} / \mathrm{kg} \mathrm{BW}$ is highly effective against adult rumen flukes in sheep. In addition, the use of a single oral dose of closantel at $10 \mathrm{mg} / \mathrm{kg} \mathrm{BW}$ is not recommended for treating paramphistomid infections in sheep.
\end{abstract}

Keywords: sheep; paramphistomidae; oxyclozanide; closantel; efficacy 


\section{Introduction}

Paramphistomids are worldwide distributed ruminal trematodes within the family Paramphistomidae [1]. Calicophoron daubneyi has been identified as the major paramphistomid in Europe, whereas Paramphistomum leydeni has also been occasionally found in sheep and wild ruminants from different European countries [2,3]. These parasites have an indirect life cycle with mud snails as intermediate hosts and both domestic and wild ruminants as definitive hosts [1,3-6]. These definitive hosts eliminate Paramphistomidae eggs in their faeces, contaminating the environment [1,7]. After hatching, miracidia infect a suitable intermediate host where it undergoes several stages of asexual reproduction (sporocyst, redia and cercaria) [1,7]. Finally, cercariae are released from the snail and encyst on the environment as metacercariae; ruminants get infected through ingestion of metacercariae with feed or water, and excysted juvenile stages considerably damage the duodenum mucosa [7]. In contrast, adult flukes, located in the rumen and reticulum, are relatively well-tolerated by the host $[8,9]$ although there is evidence that they trigger an active immune response and mucosal morphological changes in the affected ruminal papillae [10,11]. Infected animals could show unspecific clinical signs as condition loss, anorexia, dehydration and watery diarrhoea, although severe and even fatal enteritis have also been reported in cases of heavy challenge [7,8,12].

The prevalence of paramphistomid infections in domestic ruminants from Europe has been steadily growing in recent years. Although these flukes were not considered important on the European continent, being mainly linked to tropical and subtropical areas, recent investigations have reported a noticeable increase of prevalences in different European countries [7]. This trend has been particularly evident in cattle from France [13,14], United Kingdom [5,15], Ireland [10], Italy [16] and Belgium [17] as well as in sheep, especially in Ireland [2,18] and Italy [16,19]. In Spain, several studies performed in cattle from northwestern regions confirmed the same trend as in other European areas [20-23].

The progressive increase of prevalence and reports of acute cases has led to the consideration of paramphistomosis as an emergent disease of ruminants in Europe [7,24,25]. It has been suggested that this emergence may be the consequence, among others, of changes in climate conditions, importation of infected livestock, availability of more accurate diagnostic techniques, continuous deworming with anthelmintics ineffective against paramphistomids and the good adaptation of the parasite to Galba truncatula, the major intermediate host in Europe $[6,9,13,26]$. In this new scenario, finding effective control methods is currently a priority including correct management of pastures and animals as well as the availability of efficient drugs against paramphistomids. Nevertheless, the most used anthelmintics in domestic ruminants such as macrocyclic lactones or benzimidazoles have showed limited or no effect in the treatment of these flukes [27-29]. Some drugs such as niclosamide, hexachlorophene and resorantel have showed a highly variable efficacy in cattle [28], being usually more active against adult flukes. The usefulness of closantel is controversial since high [27] and limited efficacy [17,28,29] has been reported in cattle. In contrast, most investigations reported oxyclozanide as highly efficient against both juvenile and adult paramphistomids in cattle and goats $[28,30]$.

Works on the efficacy of drugs on paramphistomid infection in sheep are currently limited [31-33]. Only oxyclozanide, given orally at $20 \mathrm{mg} / \mathrm{kg}$ twice, three days apart, was proven effective in sheep [31]. Nevertheless, a single administration of a lower dosage of oxyclozanide $(15 \mathrm{mg} / \mathrm{kg}$ ) has been demonstrated highly efficient against rumen flukes in cattle, but it has not been tested in sheep. In addition, a single oral dosage of closantel at $10 \mathrm{mg} / \mathrm{kg}$ has been proven efficient in cattle [27] but no data on sheep are currently available. Thus, the aim of the present study was to assess the effectiveness of a single administration of oxyclozanide or closantel in naturally infected sheep. The results of the present study could be useful for implementing a cost-effective, less time-consuming and stressless treatment, which will be especially useful in flocks reared under extensive management. 


\section{Materials and Methods}

\subsection{Ethics Approval Statement}

All faecal samples used in this study were collected with the permission of the farm owner. All experimental procedures fully complied with European and Spanish ethics regulations on the protection of animals used for scientific purposes (European Directive 2010/63/EU and Spanish Royal Decree 53/2013) and approved by the ethical committee of the University of Santiago de Compostela.

\subsection{Experimental Design}

The study was conducted on a small commercial mixed flock of sheep and goats dedicated to meat production located in Galicia (NW Spain). All animals were maintained in a semi-extensive husbandry system, where flocks went daily to pastures near the barn and kept indoors during the night. Based on pooled results gathered from previous six-monthly coprological analyses, this farm had been positive for paramphistomids in the last two parasitological controls. No effective treatments against paramphistomids had ever been administered to any animals; however, all adults were treated with ivermectin six months before this trial.

Firstly, all adult mixed-breed sheep $(n=36)$ were sampled and weighted, in order to obtain homogeneous groups. All 25 positive ewes (average shedding of $138.8 \mathrm{epg}$ ) were included in the study; these sheep were aged from 42 to 117 months, with live-weights ranging from 40 to $70 \mathrm{~kg}$. Eleven of those positive animals also shed a small number of liver fluke eggs (average shedding of $12.7 \mathrm{epg}$ ). Using the sample() function in the R statistical package [34], positive animals were assigned to three groups showing a similar paramphistomid egg out-put:

- $\quad$ G-OXI: Nine sheep were orally treated with oxyclozanide (Rumenil ${ }^{\circledR} 34 \mathrm{mg} / \mathrm{mL}$, Karizoo, Spain) at a single dose of $15 \mathrm{mg} / \mathrm{kg}$ bodyweight.

- G-CLS: Eight animals received closantel (Endoex ${ }^{\circledR}$ 5\%, S.P. Veterinaria, Spain) at an oral single dose of $10 \mathrm{mg} / \mathrm{kg}$ bodyweight.

- $\quad$ G-CON: The remaining eight sheep were left untreated as controls.

Initial group sizes were slightly unbalanced but the number of animals per group fulfils the guidelines previously reported [35]. In addition, no statistical differences between groups considering the egg shedding intensity, age and weight were found using ANOVA test $(p>0.05)$. Each animal within those three groups was identified by a coloured necklace. The study started on November 2019 (Day 0) when the 25 animals included in the study were sampled and treated. Drugs were always administered by the same person with dosages based on the live-weight, rounded upwards to the nearest $10 \mathrm{~kg}$. Faecal samplings were performed weekly during 11 weeks, with two additional samplings at 13 and 26 weeks after treatment, in order to cover the whole prepatent period of $C$. daubneyi [11,30], considered the major species of the Paramphistomidae family in Spain and in other European countries [2,3]. After treatment, animal management practices remained unchanged; the study animals were housed together with the rest of the flock and continued grazing in the same contaminated pastures.

\subsection{Faecal Samples and Analysis}

Sampling and coprological analyses were always performed by the same investigators. Samples were collected directly from the rectum of the animals, kept at $4{ }^{\circ} \mathrm{C}$ until processing and analysed within $24 \mathrm{~h}$. A quantitative sedimentation technique was used [36] and results were expressed in epg, with a sensitivity of $2.5 \mathrm{epg}$. Regarding the limited sensitivity of the sedimentation technique, animals were considered positive since the first sampling in which paramphistomid eggs were detected. 


\subsection{Assessment of Efficacy and Statistical Analysis}

Geometric means were calculated for each group as recommended [35] in order to calculate the efficacy of each drug with the Henderson-Tilton formula [37]. This formula has been proven as the most appropriate for cases where the egg excretion of the control group fluctuates naturally during the experimental period [38]. The percentage of animals of each group shedding paramphistomid eggs was also assessed. To this end, an animal was considered positive since the first sampling it shed rumen fluke eggs.

Linear mixed effects models were carried out to evaluate whether the sampling effects of any of the two treatments were significantly different from the reference measure, i.e., control group in the day of treatment. The response variable was the $\log$ transform $(\ln (x+1))$ paramphistomid egg count; treatment and sampling week were fixed as effect variables; and the random variable was subject ID. Analysis was performed with lmer() function from lme4 package [39] in R statistical package [34]. $p$-values for mixed model were obtained with cftest() function from multcomp package [40]. Statistical differences were set at $p \leq 0.05$.

\section{Results}

Lower and more stable mean egg counts were observed in G-OXI when compared to G-CLS and G-CON groups (Figure 1).

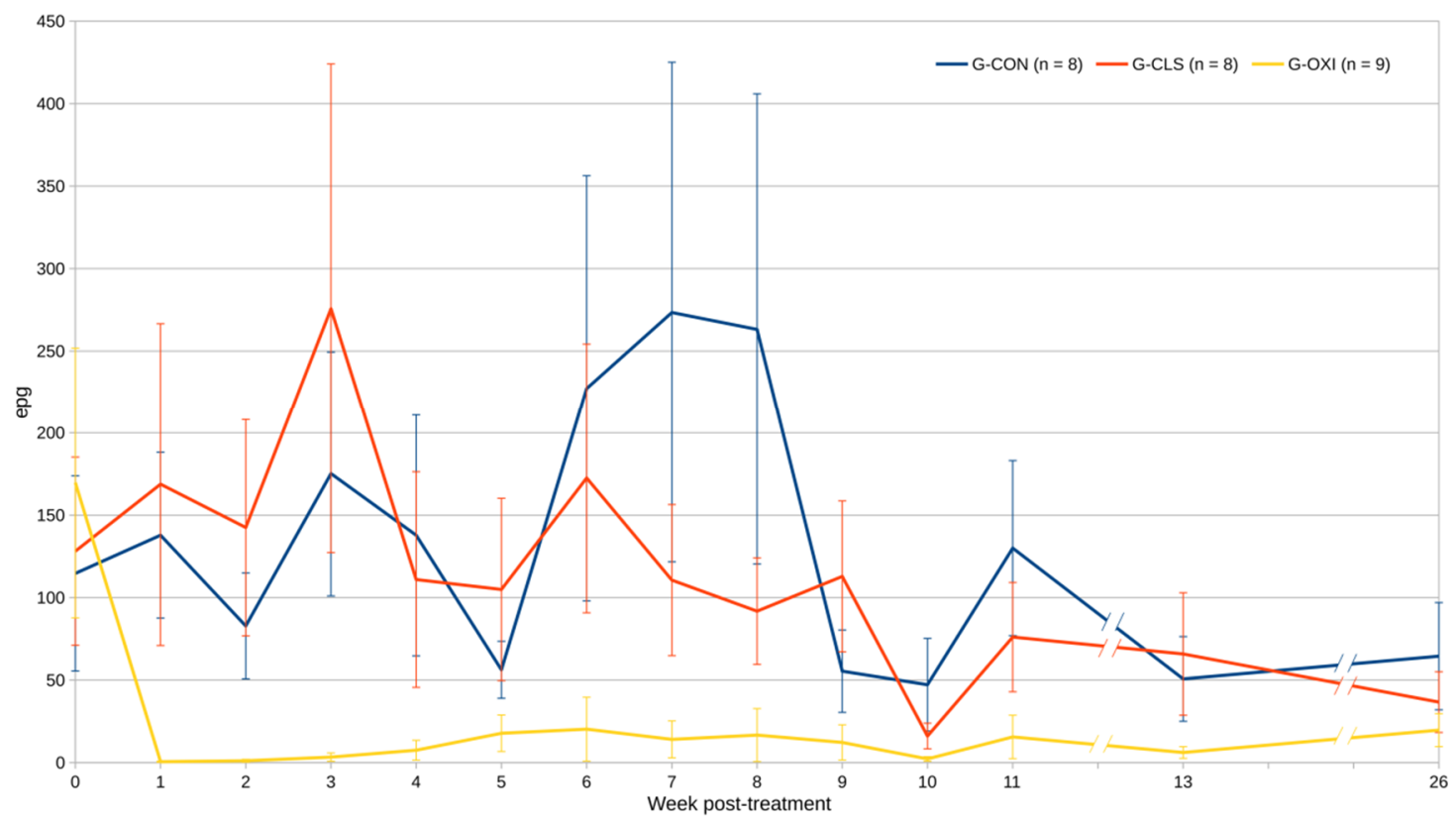

Figure 1. Arithmetic means and standard errors of paramphistomid egg shedding (eggs per gram, epg) in the three groups of sheep (G-CON, untreated controls; G-CLS, treated with closantel; G-OXI, treated with oxyclozanide) during the study period ( 26 weeks after treatment).

All G-CON sheep shed eggs during the study (Figure 2), but noticeable variations in the geometric mean egg counts were observed, with values ranging from 20.2 to 119.3 epg (Table 1). Animals from G-OXI excreted a mean number of eggs similar to G-CON before treatment (Figure 1 and Table 1). After the administration of oxyclozanide, only two sheep of G-OXI shed eggs in the first week post treatment (wpt) (Figure 2), leading to a significant reduction in the geometric mean values which remained below 3.7 epg during most of the study (Table 1). Sheep from this group became positive to paramphistomids progressively and all animals excreted eggs in the last sampling (Figure 2) where geometric mean of egg excretion intensity increased to $8.8 \mathrm{epg}$ and no significant differences with G-CON were found. In contrast, six sheep from G-CLS eliminated paramphistomid eggs since the 
first wpt, and, in the fifth wpt all animals of this group were positive (Figure 2); geometric mean egg-shedding of G-CLS was always higher than those found in G-OXI and the linear mixed effects model showed no differences in egg counts between G-CLS and G-CON throughout the study (Table 1).

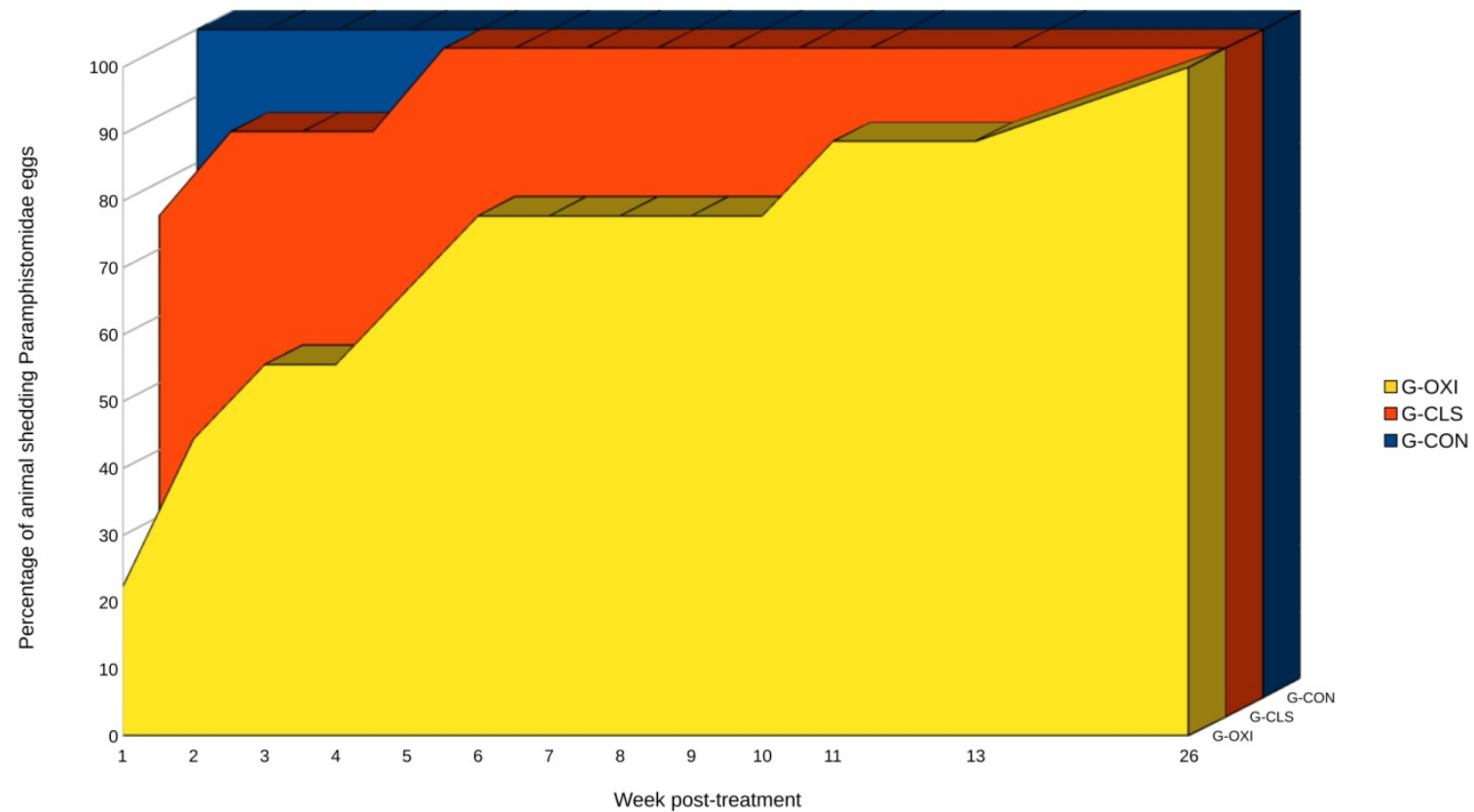

Figure 2. Percentage of animals shedding Paramphistomidae eggs detected in the three studied groups (G-OXI, G-CLS and G-CON) during study period (26 weeks after treatment). An animal was considered positive since the first sampling it shed paramphistomid eggs.

Table 1. Geometric mean egg counts in each group (G-CON, untreated controls; G-CLS, treated with closantel; G-OXI, treated with oxyclozanide) and efficacy of oxyclozanide and closantel throughout the study period (26 weeks after treatment). $p$-values for the Linear Mixed Effects Model (LMER) indicate if egg shedding in treated groups was significantly different from that in the G-CON before treatment.

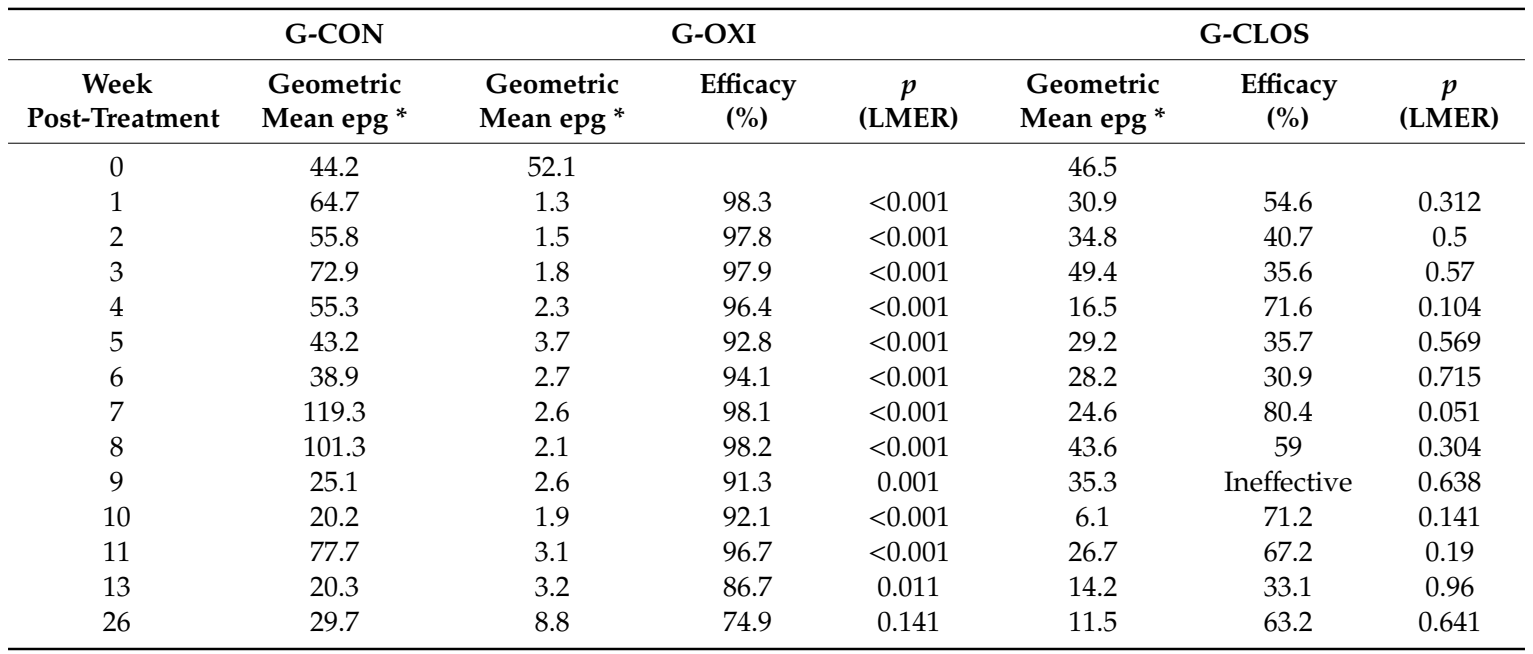

* epg, eggs per gram of faeces.

The maximum efficacy of oxyclozanide (98.3\%) was recorded in the first wpt, but effectiveness was above $90 \%$ until Week 11 (Table 1). The minimum efficacy was found in the last week of the study $(74.9 \%)$. In contrast, after applying closantel, the reduction of egg shedding was under $80 \%$ throughout the study, except in the seventh wpt when it reached $80.4 \%$ (Table 1$)$. Its minimum value $(-33.8 \%)$ was reached in the ninth wpt. 


\section{Discussion}

Geometric means of egg shedding in control group showed important variations throughout the study, ranging from 20 to $119 \mathrm{epg}$. These variations may be the consequence of natural fluctuations of paramphistomid egg shedding, including daily [4] and seasonal variations [21,41,42]. It is worth noting that a great increase on egg output was observed in all groups during seventh and eighth wpt, which corresponded to lambing season; although it has not been currently proven for trematode infections, these results may be related to a periparturient rise in faecal shedding of parasitic forms, as demonstrated for other parasites such as Cryptosporidium spp. [43,44] or gastrointestinal nematodes [45].

Our results reveal that a single dose of oxyclozanide at $15 \mathrm{mg} / \mathrm{kg}$ is very efficient against paramphistomid infections in sheep since a significant reduction in egg shedding was observed between treated and control animals and effectiveness remained above $90 \%$ during the first 11 weeks after treatment, complying with the international recommendations [35]. Since the prepatent period of C. daubneyi is considered to be 12-18 weeks [12,30], the absence of differences in egg output at the end of the study indicate that all animals have been re-infected. These results are consistent with those previously reported in domestic ruminants, showing efficiencies higher than $90 \%$ the first wpt when using a single dose ranging from 12.8 to $22.5 \mathrm{mg} / \mathrm{kg}$ BW in cows and goats $[27,29,30]$. Higher and longer efficacies have been reported when two doses are applied within a three-day interval $[28,31]$ but, from an economic and management point of view, these results do not imply a significant improvement in efficacy when compared to those obtained using a single application. Our results suggest that further research using different dosages would allow optimising the effectiveness of the treatment.

Our data suggest that oxyclozanide eliminated all adults and juvenile flukes in a small percentage of animals, since they began to shed eggs after the prepatency period [11,30]. This finding suggests that this drug has some effectiveness against intestinal stages of paramphistomids, as previously reported $[28,29]$. However, the study design does not allow a reliable measuring of the effects of this drug against juvenile paramphistomids since the initial parasite burden in the duodenum and abomasum was not known. In contrast, more than $50 \%$ of sheep of G-OXI shed eggs in the fourth wpt or earlier, indicating that the drug had eliminated adults but not all juvenile paramphistomids. In addition, two animals were positive from the first wpt and efficacies of $100 \%$ were never recorded after a single treatment with oxyclozanide at $15 \mathrm{mg} / \mathrm{kg}$, revealing that adult flukes were not completely eliminated in some animals. However, this study agrees with previous research reporting that oxyclozanide is an efficient and reliable anthelmintic for treating adult paramphistomids affecting domestic ruminants. In addition, our results show that G-OXI animals shed fewer eggs than G-CLS and G-CON, thus treating animals with oxyclozanide also reduces environment contamination with paramphistomid eggs and, consequently, infection in the intermediate host. Nevertheless, it is worth noting that an adequate control of rumen fluke infection in domestic ruminants should also involve suitable pasture management, including fencing in snail habitats, drenching or rotational grazing [46,47].

The efficacy of closantel in reducing paramphistomid egg output was low and irregular during the present study, never exceeding $81 \%$; in addition, the percentage of positive animals was always over $70 \%$ after the treatment, and all sheep were positive in the fifth wpt. Thus, our data indicate that closantel was not efficient against both adult and juvenile rumen flukes in sheep when administered orally at $10 \mathrm{mg} / \mathrm{kg}$. These results are in agreement with previous investigations reporting the absence of a significant reduction in the number of immature paramphistomids after treating cattle with a single dose of closantel at $7.5 \mathrm{mg} / \mathrm{kg}$ BW orally [28] and $10 \mathrm{mg} / \mathrm{kg}$ BW intraruminally [29]. In this regard, it has also been observed that a subcutaneous administration of closantel at $10 \mathrm{mg} / \mathrm{kg}$ was not efficient in reducing $C$. daubneyi egg shedding [17]. In contrast, the oral administration of this drug at single dose of $10 \mathrm{mg} / \mathrm{kg}$ BW was found effective against adult paramphistomids in adult cattle [27]. These discrepancies may be the consequence of using different administration routes [27]. Although using the same efficient deworming protocol previously reported in cattle [27], the low efficacy of 
closantel found in this study may be related to variations in the sensitivity of the detection techniques used, as well as to differences in drug pharmacokinetics or pharmacodynamics between sheep and cattle, as previously reported for other anthelmintics [48].

\section{Conclusions}

According to the present study, the situation of pharmacological control of paramphistomids in sheep is far from desirable. Oxyclozanide is the only anthelmintic showing a good performance against rumen flukes currently available in sheep; thus, strategic treatments together with complementary control measures for reducing pasture parasitic burden [47] are strongly recommended. Without other effective drugs available and rumen fluke prevalences increasing in Europe [7,49], finding new alternatives for the control of rumen flukes should be considered a priority.

Author Contributions: Conceptualisation, D.G.-D. and C.M.L.; methodology, M.V.; formal analysis, C.M.L. and J.M.D.C.; investigation, D.G.-D., P.D., A.P. and S.R.; resources, M.V.; writing—original draft preparation, D.G.-D. and P.D.; writing-review and editing, P.D., R.P., P.D.-B. and C.M.L.; visualisation, G.L.-L.; supervision, P.D.; and funding acquisition, P.D.-B. All authors have read and agreed to the published version of the manuscript.

Funding: This research was funded by the Program for consolidating and structuring competitive research groups (Xunta de Galicia, Spain), grant number 2017-PG117.

Acknowledgments: The authors thank OVICA (Galician Association of Ovine and Caprine Breeders), the veterinarians of ADSG ACIVO and the farmer for their collaboration in this study; S.P. Veterinaria and Karizoo for providing the pharmacological products; and Paula Díez Berengeno for their invaluable help in collecting the samples.

Conflicts of Interest: The authors declare no conflict of interest.

\section{References}

1. Horak, I.G. Paramphistomiasis of domestic ruminants. Adv. Parasitol. 1971, 9, 33-72. [CrossRef]

2. Martinez-Ibeas, A.M.; Munita, M.P.; Lawlor, K.; Sekiya, M.; Mulcahy, G.; Sayers, R. Rumen fluke in Irish sheep: Prevalence, risk factors and molecular identification of two paramphistome species. BMC Vet. Res. 2016, 12, 143. [CrossRef] [PubMed]

3. O'Toole, A.; Browne, J.; Hogan, S.; Bassière, T.; DeWaal, T.; Mulcahy, G.; Zintl, A. Identity of rumen fluke in deer. Parasitol. Res. 2014, 113, 4097-4103. [CrossRef] [PubMed]

4. Horak, I.G. Host-parasite relationships of Paramphistomum microbothrium Fischoeder, 1901, in experimentally infested ruminants, with particular reference to sheep. Onderstepoort J. Vet. Res. 1967, 34, 451-540. [PubMed]

5. Huson, K.M.; Brophy, P.M.; Morphew, R.M.; MacKintosh, N.D. Identification of the rumen fluke Calicophoron daubneyi infecting cattle in Wales. Adv. Anim. Biosci. 2015, 6, 183. [CrossRef]

6. Jones, R.A.; Williams, H.W.; Dalesman, S.; Brophy, P.M. Confirmation of Galba truncatula as an intermediate host snail for Calicophoron daubneyi in Great Britain, with evidence of alternative snail species hosting Fasciola hepatica. Parasit. Vectors 2015, 8, 656. [CrossRef]

7. Huson, K.M.; Oliver, N.A.M.; Robinson, M.W. Paramphistomosis of ruminants: An emerging parasitic disease in Europe. Trends. Parasitol. 2017, 33, 836-844. [CrossRef] [PubMed]

8. Millar, M.; Colloff, A.; Scholes, S. Bovine health: Disease associated with immature paramphistome infection. Vet. Rec. 2012, 171, 509-510. [CrossRef] [PubMed]

9. Zintl, A.; Garcia-Campos, A.; Trudgett, A.; Chryssafidis, A.L.; Talavera-Arce, S.; Fu, Y.; Egan, S.; Lawlor, A.; Negredo, C.; Brennan, G.; et al. Bovine paramphistomes in Ireland. Vet. Parasitol. 2014, 204, 199-208. [CrossRef]

10. Díaz, P.; Lomba, C.; Pedreira, J.; Arias, M.; Sánchez-Andrade, R.; Suárez, J.L.; Díez-Baños, P.; Morrondo, P.; Paz-Silva, A. Analysis of the IgG antibody response against Paramphistomidae trematoda in naturally infected cattle. Vet. Parasitol. 2006, 140, 281-288. [CrossRef]

11. Fuertes, M.; Manga-González, Y.; Benavides, J.; González-Lanza, M.C.; Giráldez, F.J.; Mezo, M.; González-Warleta, M.; Fernández, M.; Regidor-Cerrillo, J.; Castaño, P.; et al. Immunohistochemical study and mRNA cytokine profile of the local immune response in cattle naturally infected with Calicophoron daubneyi. Vet. Parasitol. 2015, 214, 178-183. [CrossRef] [PubMed] 
12. Mason, C.; Stevenson, H.; Cox, A.; Dick, I. Disease associated with immature paramphistome infection in sheep. Vet. Rec. 2012, 170, 343-344. [CrossRef] [PubMed]

13. Mage, C.; Bourgne, H.; Toullieu, J.; Rondelaud, D.; Dreyfuss, G. Fasciola hepatica and Paramphistomum daubneyi: Changes in prevalences of natural infections in cattle and in Lymnaea truncatula from central France over the past 12 years. Vet. Res. 2002, 33, 439-447. [CrossRef] [PubMed]

14. Szmidt-Adjidé, V.; Abrous, M.; Adjidé, C.C.; Dreyfuss, G.; Lecompte, A.; Cabaret, J.; Rondelaud, D. Prevalence of Paramphistomum daubneyi infection in cattle in central France. Vet. Parasitol. 2000, 87, 133-138. [CrossRef]

15. Gordon, D.K.; Roberts, L.C.P.; Lean, N.; Zadoks, R.N.; Sargison, N.D.; Skuce, P.J. Identification of the rumen fluke, Calicophoron daubneyi, in GB livestock: Possible implications for liver fluke diagnosis. Vet. Parasitol. 2013, 195, 65-71. [CrossRef]

16. Sanna, G.; Varcasia, A.; Serra, S.; Salis, F.; Sanabria, R.; Pipia, A.P.; Dore, F.; Scala, A. Calicophoron daubneyi in sheep and cattle of Sardinia, Italy. Helminthologia 2016, 53, 87-93. [CrossRef]

17. Malrait, K.; Verschave, S.; Skuce, P.; van Loo, H.; Vercruysse, J.; Charlier, J. Novel insights into the pathogenic importance, diagnosis and treatment of the rumen fluke (Calicophoron daubneyi) in cattle. Vet. Parasitol. 2015, 207, 134-139. [CrossRef]

18. Toolan, D.P.; Mitchell, G.; Searle, K.; Sheehan, M.; Skuce, P.J.; Zadoks, R.N. Bovine and ovine rumen fluke in Ireland-Prevalence, risk factors and species identity based on passive veterinary surveillance and abattoir findings. Vet. Parasitol. 2015, 212, 168-174. [CrossRef]

19. Cringoli, G.; Taddei, R.; Rinaldi, L.; Veneziano, V.; Musella, V.; Cascone, C.; Sibilio, G.; Malone, J.B. Use of remote sensing and geographical information systems to identify environmental features that influence the distribution of paramphistomosis in sheep from the southern italian apennines. Vet. Parasitol. 2004, 122, 15-26. [CrossRef]

20. Arias, M.; Lomba, C.; Dacal, V.; Vázquez, L.; Pedreira, J.; Francisco, I.; Piñeiro, P.; Cazapal-Monteiro, C.; Suárez, J.L.; Díez-Baños, P.; et al. Prevalence of mixed trematode infections in an abattoir receiving cattle from northern Portugal and north-west Spain. Vet. Rec. 2011, 168, 408. [CrossRef]

21. Díaz, P.; Pedreira, J.; Sánchez-Andrade, R.; Suárez, J.; Arias, M.; Francisco, I.; Fernández, G.; Díez-Baños, P.; Morrondo, P.; Paz-Silva, A. Risk periods of infection by Calicophoron daubneyi (Digenea: Paramphistomidae) in cattle from oceanic climate areas. Parasitol. Res. 2007, 101, 339-342. [CrossRef]

22. González-Warleta, M.; Lladosa, S.; Castro-Hermida, J.A.; Martínez-Ibeas, A.M.; Conesa, D.; Muñoz, F.; López-Quílez, A.; Manga-González, Y.; Mezo, M. Bovine paramphistomosis in Galicia (Spain): Prevalence, intensity, aetiology and geospatial distribution of the infection. Vet. Parasitol. 2013, 191, 252-263. [CrossRef] [PubMed]

23. Sanchís, J.; Sánchez-Andrade, R.; Macchi, M.I.; Piñeiro, P.; Suárez, J.L.; Cazapal-Monteiro, C.; Maldini, G.; Venzal, J.M.; Paz-Silva, A.; Arias, M.S. Infection by Paramphistomidae trematodes in cattle from two agricultural regions in NW Uruguay and NW Spain. Vet. Parasitol. 2013, 191, 165-171. [CrossRef] [PubMed]

24. Alzieu, J.; Dorchies, P. Réémergence de la paramphistomose bovine en France: Synthèse des connaissances actuelles épidémiologiques, physiopathologiques et diagnostiques. Bull. Acad. Vet. Fr. 2007, 2, 93. [CrossRef]

25. Jones, R.A.; Brophy, P.M.; Mitchell, E.S.; Williams, H.W. Rumen fluke (Calicophoron daubneyi) on Welsh farms: Prevalence, risk factors and observations on co-infection with Fasciola hepatica. Parasitology 2017, 144, 237-247. [CrossRef] [PubMed]

26. Iglesias-Piñeiro, J.; González-Warleta, M.; Castro-Hermida, J.A.; Córdoba, M.; González-Lanza, C.; Manga-González, Y.; Mezo, M. Transmission of Calicophoron daubneyi and Fasciola hepatica in Galicia (Spain): Temporal follow-up in the intermediate and definitive hosts. Parasit. Vectors 2016, 9, 1-14. [CrossRef] [PubMed]

27. Arias, M.S.; Sanchís, J.; Francisco, I.; Francisco, R.; Piñeiro, P.; Cazapal-Monteiro, C.; Cortiñas, F.J.; Suárez, J.L.; Sánchez-Andrade, R.; Paz-Silva, A. The efficacy of four anthelmintics against Calicophoron daubneyi in naturally infected dairy cattle. Vet. Parasitol. 2013, 197, 126-129. [CrossRef]

28. Rolfe, P.F.; Boray, J.C. Chemotherapy of paramphistomosis in cattle. Aust. Vet. J. 1987, 64, 328-332. [CrossRef]

29. Rolfe, P.; Boray, J. Comparative efficacy of moxidectin, an ivermectin/clorsulon combination and closantel against immature paramphistomes in cattle. Aust. Vet. J. 1993, 70, 265-266. [CrossRef]

30. Paraud, C.; Gaudin, C.; Pors, I.; Chartier, C. Efficacy of oxyclozanide against the rumen fluke Calicophoron daubneyi in experimentally infected goats. Vet. J. 2009, 180, 265-267. [CrossRef] 
31. Sanabria, R.; Moreno, L.; Alvarez, L.; Lanusse, C.; Romero, J. Efficacy of oxyclozanide against adult Paramphistomum leydeni in naturally infected sheep. Vet. Parasitol. 2014, 206, 277-281. [CrossRef] [PubMed]

32. Boray, J.C. The anthelmintic efficiency of niclosamide and menichlopholan in the treatment of intestinal Paramphistomosis in sheep. Aust. Vet. J. 1969, 45, 133-134. [CrossRef] [PubMed]

33. Rolfe, P.F.; Boray, J.C. Chemotherapy of paramphistomosis in sheep. Aust. Vet. J. 1988, 65, 148-150. [CrossRef]

34. R Core Team. R: A Language and Environment for Statistical Computing; R Foundation for Statistical Computing: Vienna, Austria, 2020; Available online: https://www.R-project.org/ (accessed on 14 September 2020).

35. Vercruysse, J.; Holdsworth, P.; Letonja, T.; Barth, D.; Conder, G.; Hamamoto, K.; Okano, K. International harmonisation of anthelmintic efficacy guidelines. Vet. Parasitol. 2001, 96, 171-193. [CrossRef]

36. Foreyt, W.J. Veterinary Parasitology Reference Manual, 5th ed.; Iowa State University Press: Ames, IA, USA, 2001; p. 244.

37. Henderson, C.F.; Tilton, E.W. Tests with acaricides against the brown wheat mite. J. Econ. Entomol. 1955, 48, 157-161. [CrossRef]

38. Geurden, T.; Olson, M.E.; O'Handley, R.M.; Schetters, T.; Bowman, D.; Vercruysse, J. World association for the advancement of veterinary parasitology (WAAVP): Guideline for the evaluation of drug efficacy against non-coccidial gastrointestinal protozoa in livestock and companion animals. Vet. Parasitol. 2014, 204, 81-86. [CrossRef]

39. Bates, D.; Maechler, M.; Bolker, B.; Walker, S. Fitting Linear Mixed-Effects Models using lme4. J. Stat. Softw. 2015, 67, 1-48. [CrossRef]

40. Hothorn, T.; Bretz, F.; Westfall, P. Simultaneous Inference in General Parametric Models. Biom. J. 2008, 50, 346-363. [CrossRef]

41. Phiri, A.M.; Chota, A.; Phiri, I.K. Seasonal pattern of bovine amphistomosis in traditionally reared cattle in the Kafue and Zambezi catchment areas of Zambia. Trop. Anim. Health Prod. 2007, 39, 97-102. [CrossRef] [PubMed]

42. Rangel-Ruiz, L.J.; Albores-Brahms, S.T.; Gamboa-Aguilar, J. Seasonal trends of Paramphistomum cervi in Tabasco, Mexico. Vet. Parasitol. 2003, 116, 217-222. [CrossRef]

43. Dessì, G.; Tamponi, C.; Varcasia, A.; Sanna, G.; Pipia, A.P.; Carta, S.; Salis, F.; Díaz, P.; Scala, A. Cryptosporidium infections in sheep farms from Italy. Parasitol. Res.. in press.

44. De Waele, V.; Berzano, M.; Speybroeck, N.; Berkvens, D.; Mulcahy, G.M.; Murphy, T.M. Peri-parturient rise of cryptosporidium oocysts in cows: New insights provided by duplex quantitative real-time PCR. Vet. Parasitol. 2012, 189, 366-368. [CrossRef] [PubMed]

45. Notter, D.R.; Burke, J.M.; Miller, J.E.; Morgan, J.L.M. Factors affecting fecal egg counts in periparturient Katahdin ewes and their lambs. J. Anim. Sci. 2017, 95, 103-112. [CrossRef] [PubMed]

46. Morley, F.H.W.; Donald, A.D. Farm management and systems of helminth control. Vet. Parasitol. 1980, 6, 105-134. [CrossRef]

47. Rolfe, P.F.; Boray, J.C.; Nichols, P.; Collins, G.H. Epidemiology of paramphistomosis in cattle. Int. J. Parasitol. 1991, 21, 813-819. [CrossRef]

48. Lanusse, C.E.; Nare, B.; Prichard, R.K. Comparative sulphoxidation of albendazole by sheep and cattle liver microsomes and the inhibitory effect of methimazole. Xenobiotica 1993, 23, 285-295. [CrossRef]

49. Taylor, M.A. Emerging parasitic diseases of sheep. Vet. Parasitol. 2012, 189, 2-7. [CrossRef]

Publisher's Note: MDPI stays neutral with regard to jurisdictional claims in published maps and institutional affiliations.

(C) 2020 by the authors. Licensee MDPI, Basel, Switzerland. This article is an open access article distributed under the terms and conditions of the Creative Commons Attribution (CC BY) license (http://creativecommons.org/licenses/by/4.0/). 